\title{
Diagnosis of Exocrine Pancreatic Insufficiency in the Dog Using Radial Enzyme Diffusion
}

\author{
K. VONDRÁKOVÁ, J. KLIMEŠ ${ }^{1}$
}

Small Animal Clinic, Faculty of Veterinary Medicine, ${ }^{1}$ Present Adress:

${ }^{1}$ Department of Biology and Wildlife Diseases, Faculty of Veterinary Hygiene and Ecology, University of Veterinary and Pharmaceutical Sciences, Brno, Czech Republic

\section{Received September 9, 2001}

Accepted June 19, 2002

\section{Abstract}

Vondráková K., J. Klimeš: Diagnosis of Exocrine Pancreatic Insufficiency in the Dog Using Radial Enzyme Diffusion. Acta Vet. Brno 2002, 71: 223-228.

Exocrine pancreatic insufficiency (EPI) is an important cause of chronic diarrhoea in dogs, which should be reliably excluded before proceeding to the more invasive diagnostic methods like endoscopy. The aim of the present study was to validate the radial enzyme diffusion (RED) as one of the diagnostic techniques for canine EPI based on measurement of faecal proteolytic activity. The modification of RED is described where a water solution of skim milk is used instead of Caparacaseinate as a substrate for pancreatic proteases. Serum trypsin-like immunoreactivity (TLI) with $100 \%$ specificity and sensitivity was used as a reference technique. The RED was validated in 24 dogs mostly with chronic diarrhoea. Dogs of various breeds were examined with German shepherds over-represented. Ten clinically healthy dogs were used as controls. In each dog, 3 consecutive faecal samples were examined. In all dogs, serum samples were examined for TLI. Sensitivity of $100 \%$ and specificity of $75 \%$ were calculated for RED. Possible causes of falsely positive and falsely negative results of RED and TLI are discussed. The RED has proven to be a quick, cheap and easy-to-perform method suitable for reliable exclusion of those cases where the diarrhoea is not caused by EPI. However, regarding its lower specificity, positive results should be confirmed by TLI assay.

Pancreas, dog, faecal proteolytic activity, trypsin-like immunoreactivity

Exocrine pancreatic insufficiency (EPI) is an important cause of malassimilation and chronic diarrhoea in dogs. The most frequent cause of EPI is pancreatic acinar atrophy which is inherited in an autosomal recessive manner in German shepherd dogs (Freudiger 1991; Hall et al. 1991; Rallis et al. 1999) and rough - coated collies (Westermarck et al. 1993; Fischer and Müller 1994; Wiberg et al. 1999). The EPI can also be a result of chronic relapsing pancreatitis and rarely of severe acute pancreatitis or neoplasia (Hall and Hage moser 1990; Freudiger 1991; Spillmann 1996). Another potential cause could be an obstruction of the pancreatic duct due to spasms, inflammation, calculi or parasites (Spillmann 1996).

The insufficiency of exocrine pancreas is clinically observable only after a 85-90\% loss of the functional tissue (Freudiger 1991; Westermarck et al. 1993; Fischer and Müller 1994). The clinical signs caused by small intestinal maldigestion and malabsorption include polyphagia, coprophagia, weight loss, chronic diarrhoea with frequency 3-8 per day, steatorrhoea, voluminous faeces with presence of undigested particles, poor condition of the haircoat, flatulence and borborygmi (Räihä and Westermarck 1989, Freudiger 1991; Fischer and Müller 1994).

It is not possible to distinguish EPI clinically from other causes of malabsorption at an early stage of the disease. Although less common than inflammatory bowel disease and other enteropathies, EPI should first be excluded as a potential cause of chronic small bowel diarrhoea before proceeding to the more invasive endoscopic examination.

Survey diagnosis of EPI is based on several main principles. Nowadays, the gold standard 
is measuring canine serum trypsin-like immunoreactivity (TLI) using radioimmunoassay (RIA) (Hall et al. 1991; Boari et al. 1994). Trypsin is specifically pancreatic in origin (Simpson et al. 1991) and concentrations of trypsin and trypsinogen in blood express the level of their production in pancreas. Williams and Batt (1988) reported a 100\% sensitivity and specificity of this test.

Another approach involves techniques based on measuring faecal proteolytic activity. All these methods can provide the same kind of false results, because of the variability of conditions in the intestine including changes in bacterial colonisation which can rapidly alter the amount and function of proteolytic enzymes in the bowel (Williams and B att 1988; Spillmann 1996). Radial enzyme diffusion (RED) is a semiquantitative method where Ca-paracaseinate or a product of rennet precipitation of skimmed milk in the agar layer is split down by proteases from faeces (Westermarck and S and holm 1980). Similarly, the concentration of trypsin and chymotrypsin in faeces can be measured colorimetrically (Freudiger 1991; Fischer and Müller 1994; Spillmann 1996).

The so called bentiromide-PABA test is a functional assay, which also detects the activity of chymotrypsin in the lumen of the small bowel (Williams and B att 1988; Freudiger 1991; Spillmann 1996; Spillmann et al. 1998). A variety of other less accurate tests exist, but due to their poor diagnostic value these tests are no more recommended.

Because of certain problems regarding TLI-based diagnosis of EPI (relatively high costs of analysis, low number of samples, difficulties in sending samples abroad), we searched for a cheaper and yet reasonably reliable diagnostic technique. The goal of this study was to determine diagnostic value of our modification of RED in EPI diagnosis, in comparison with serum TLI assay as a reference technique. Clinical signs compatible with the diagnosis were also considered.

\section{Materials and Methods}

Two different methods were used for diagnosis of exocrine pancreatic insufficiency in dogs, namely canine trypsin-like immunoreactivity (TLI) and radial enzyme diffusion (RED). Radioimmunoassay of TLI was performed in a human commercial RIA laboratory (Soukromá imunoanalytická a mikrobiologická laboratoř, Brno), using a commercial Canine TLI Assay (Double Antibody Canine TLI, Diagnostic Products Corporation, Los Angeles, USA). The Double Antibody procedure is a liquid-phase radioimmunoassay, wherein ${ }^{125}$ I-labeled TLCK-inactivated trypsin competes with both trypsin and trypsinogen in the canine serum sample for antibody sites. After incubation, separation of bound from free fraction is achieved by the PEG-accelerated Double Antibody method. The antibody bound fraction is precipitated and counted. Patient sample concentrations are read from a calibration curve. Obtained values of concentration between $5-35 \mathrm{ng} / \mathrm{ml}$ were considered as normal, values in range $0-2.5 \mathrm{ng} / \mathrm{ml}$ as diagnostic for EPI and values in range $2.5-5 \mathrm{ng} / \mathrm{ml}$ as dubious (Hall et al. 1990).

Diagnosis of EPI using RED was performed by the first author in the laboratory of the Department of Microbiology and Immunology, University of Veterinary and Pharmaceutical Sciences Brno, Czech Republic. The technique is a modification of the classical procedure (Westermarck et al. 1980) where a water solution of skim milk is used instead of Ca-paracaseinate as a substrate for pancreatic proteases. This modification was obtained from Prof. M. Sandholm, Dept. of Clinical Sciences, Faculty of Veterinary Medicine, Helsinki University (personal communication, 1999) and to our knowledge has not yet been published.

A water solution of skim milk (Oxoid) was mixed with agarose (Agarosa pro elektroforézu, Lachema, Czech Republic) and Sodium Azide (Merck) dissolved in TRIS-HCl buffer (Merck). Prepared mixture was poured between two $(10 \times 10 \mathrm{~cm})$ glass plates. Six wells (diameter $6 \mathrm{~mm}$ ) were punched out of the obtained agar layer and these were filled with the supernatant. Supernatant was prepared by mixing $0.5 \mathrm{~g}$ of faeces and $4.5 \mathrm{ml}$ of $4.2 \%$ $\mathrm{NaHCO}_{3}$ (Natrium hydrogencarbonicum, Léčiva, Czech Republic) and subsequent centrifugation of the mixture. The plates were incubated for 20 hours in humid chamber at room temperature. Subsequently, the radius of the cleared zones was measured using slide callipers. The absence of cleared zones in the agar layer after the incubation time indicated presence of EPI. When cleared zones around the wells were found, the result was EPI-negative.

Twenty-four dogs of various breeds and ages with signs mostly of chronic diarrhoea were examined using RED and TLI assay. The dogs ranged in age from 3 months to 7 years. There were 17 males and 7 females, 3 cross-breds and 21 different pure breeds with German shepherds (8) most often represented. Among 10 clinically healthy controls ranging in age from 5 months to 11 years there were 4 males and 6 females, 4 mongrels and 6 pure breeds.

Three samples of faeces from each dog were collected for three subsequent days and directly examined. Serum samples were taken from every patient and control dog and stored at a temperature of $-20{ }^{\circ} \mathrm{C}$ till analysis. Faeces 
Table 1

Evaluation of clinical signs typical of EPI using the numbered scoring system and comparison with the results of RED and serum TLI

\begin{tabular}{|c|c|c|c|c|c|c|c|c|c|c|c|}
\hline Nr. & appetite & $\begin{array}{l}\text { weight } \\
\text { loss }\end{array}$ & $\begin{array}{l}\text { presence } \\
\text { of chron. } \\
\text { diarrhea }\end{array}$ & \begin{tabular}{|c|} 
frequency \\
of \\
defecation
\end{tabular} & $\begin{array}{c}\text { consistency } \\
\text { of faeces }\end{array}$ & \begin{tabular}{|c|} 
volume \\
of faeces
\end{tabular} & $\begin{array}{l}\text { greasy } \\
\text { look of } \\
\text { faeces }\end{array}$ & flatulence & total & $\begin{array}{c}\text { RED } \\
\text { results } \\
(\mathrm{cm}) \\
\end{array}$ & $\begin{array}{c}\text { TLI } \\
\text { results } \\
\text { (ng/ml) }\end{array}$ \\
\hline \multicolumn{12}{|c|}{ EPI - POSITIVE CASES } \\
\hline 1. & 3 & 2 & 2 & 2 & 3 & 1 & 2 & 1 & 16 & 0 & 0.67 \\
\hline 2. & 3 & 2 & 2 & 3 & 3 & 2 & 2 & 2 & 19 & 0 & 0.55 \\
\hline 3. & 3 & 2 & 2 & 2 & 3 & 2 & 2 & 2 & 18 & 0 & 0.65 \\
\hline 4. & 3 & 2 & 2 & 3 & 3 & 1 & 1 & 2 & 17 & 0 & 0.73 \\
\hline 5. & 3 & 1 & 2 & 3 & 3 & 2 & 1 & 2 & 17 & 0 & 1.89 \\
\hline 6. & 3 & 2 & 2 & 2 & 3 & 1 & 1 & 2 & 16 & 0 & 0.70 \\
\hline 7. & 3 & 2 & 2 & 1 & 3 & 1 & 1 & 1 & 14 & 0 & 1.03 \\
\hline 8. & 3 & 1 & 2 & 3 & 3 & 1 & 1 & 2 & 16 & 0 & 1.25 \\
\hline \multicolumn{12}{|c|}{ EPI - NEGATIVE CASES } \\
\hline 9. & 3 & 1 & 2 & \begin{tabular}{|l|}
3 \\
\end{tabular} & 1 & 1 & 1 & 2 & 14 & 0 & 6.99 \\
\hline 10. & 3 & 2 & 2 & 3 & 3 & 1 & 1 & 2 & 17 & 0 & 8.86 \\
\hline 11. & 2 & 1 & 1 & 3 & 3 & 1 & 1 & 1 & 13 & 0 & 15.00 \\
\hline 12. & 1 & 1 & 2 & 1 & 3 & 1 & 1 & 2 & 12 & 0 & 11.41 \\
\hline 13. & 1 & 2 & 2 & 3 & 3 & 2 & 1 & 2 & 16 & 0.25 & 7.76 \\
\hline 14. & 3 & 2 & 2 & 2 & 3 & 2 & 1 & 2 & 17 & 0.50 & 6.62 \\
\hline 15. & 1 & 2 & 2 & 1 & 3 & 1 & 1 & 1 & 12 & 0.60 & 11.18 \\
\hline 16. & 2 & 2 & 2 & 1 & 3 & 1 & 1 & 1 & 13 & 0.70 & 10.15 \\
\hline 17. & 1 & 1 & 1 & 1 & 3 & 1 & 1 & 1 & 10 & 0.70 & 6.57 \\
\hline 18. & 2 & 1 & 2 & 1 & 3 & 1 & 1 & 2 & 13 & 0.70 & 9.80 \\
\hline 19. & 1 & 1 & 2 & 1 & 3 & 2 & 1 & 2 & 13 & 0.50 & 14.04 \\
\hline 20. & 1 & 2 & 2 & 3 & 3 & 1 & 1 & 1 & 14 & 0.65 & 22.60 \\
\hline 21. & 3 & 1 & 2 & 1 & 3 & 1 & 1 & 1 & 13 & 0.60 & 11.97 \\
\hline 22. & 3 & 2 & 2 & 1 & 3 & 1 & 1 & 2 & 15 & 0.70 & 11.20 \\
\hline 23. & 1 & 1 & 1 & 1 & 3 & 1 & 1 & 1 & 10 & 0.60 & 8.72 \\
\hline 24. & 3 & 1 & 2 & 1 & 3 & 1 & 1 & 2 & 14 & 0.70 & 17.62 \\
\hline \multicolumn{12}{|c|}{ HEALTHY CONTROLS } \\
\hline 25. & 1 & 1 & 1 & 1 & 1 & 1 & 1 & 1 & 8 & 0.7 & 15.75 \\
\hline 26. & 1 & 1 & 1 & 1 & 1 & 1 & 1 & 1 & 8 & 0.5 & 15.49 \\
\hline 27. & 1 & 1 & 1 & 1 & 1 & 1 & 1 & 1 & 8 & 0.5 & 9.08 \\
\hline 28. & 1 & 1 & 1 & 1 & 1 & 1 & 1 & 1 & 8 & 0.5 & 13.51 \\
\hline 29. & 1 & 1 & 1 & 1 & 1 & 1 & 1 & 1 & 8 & 0.3 & 11.9 \\
\hline 30. & 1 & 1 & 1 & 1 & 1 & 1 & 1 & 1 & 8 & 0.75 & 15.96 \\
\hline 31. & 1 & 1 & 1 & 1 & 1 & 1 & 1 & 1 & 8 & 0.75 & 15.01 \\
\hline 32. & 1 & 1 & 1 & 1 & 1 & 1 & 1 & 1 & 8 & 0.7 & 14.05 \\
\hline 33. & 1 & 1 & 1 & 1 & 1 & 1 & 1 & 1 & 8 & 0.7 & 13.23 \\
\hline 34. & 1 & 1 & 1 & 1 & 1 & 1 & 1 & 1 & 8 & 0.7 & 10.13 \\
\hline
\end{tabular}

Characteristic signs of EPI were assessed by the owners. Signs were scored in such a way that the more typical the symptom of EPI, the higher the score.

appetite

$1=$ normal

$2=$ poor

$3=$ excessive

weight loss

$1=$ not present

$2=$ present

chronic diarrhea

$1=$ not present

$2=$ present

volume of faeces

$1=$ normal

$2=$ copious

greasy look of faeces

$1=$ not present

$2=$ present frequency of defecation

$1=$ less than 3 times a day

$2=$ more than 8 times a day

$3=3-8$ times a day

consistency of faeces

$1=$ normal

$2=$ watery

3 = pulpy, maldigested

flatulence

$1=$ not present

$2=$ present 
and serum samples were either sent for analysis by private veterinary practitioners or obtained from the patients of the Small Animal Clinic, University of Veterinary and Pharmaceutical Sciences Brno. In every examined dog, a gastroenterology history questionnaire has been completed by referring veterinarian or the author. Information from the gastroenterological history questionnaires was evaluated regarding an occurrence of the clinical signs most typical of EPI; it was presence of chronic diarrhoea, volume of the faeces, frequency of defecation, consistency of faeces, greasy look of faeces, weight loss, polyphagia and flatulence. Presence or absence of these signs was assessed using the "numbered scoring system", as is shown in Table 1. Summing up the points in each case we got a definitive number, which characterised the possibility of occurrence of EPI - the higher score the case achieved, the higher was the probability of EPI. These data were used for completing the diagnosis.

The specificity and sensitivity of RED was calculated.

\section{Results}

Using RED, 12 animals out of 24 examined dogs with chronic diarrhoea were EPIpositive and 12 dogs EPI-negative. All 10 controls were negative (Table 1).

The diagnosis of EPI was confirmed by means of TLI. EPI was diagnosed only in 8 dogs. The remaining 14 animals with diarrhoea and all 10 healthy controls were negative (Table1).

The calculated sensitivity of RED was $100 \%$ and specificity $75 \%$. Results of the evaluation of clinical signs using the numbered scoring system are shown in Table 1.

\section{Discussion}

In the present study, TLI was used as a reference technique due to its exceptionally high sensitivity (100\%) and specificity (100\%), as determined by Williams and Batt (1988). There was a difference between RED and TLI results in 4 dogs with diarrhoea. These RED results were considered as falsely positive decreasing thus the specificity of RED, which was calculated to be $75 \%$. The severity of clinical signs in these 4 patients was variable; dogs No 11 and 12 (Table 1) showed only few signs typical of EPI and both dogs improved on a diet based on a single protein source. The other two dogs, especially No 10, clinically correspond to EPI quite well. Unfortunately, in these two cases it was not possible to proceed with diagnostic work-up because the contact with the owners had been lost.

All the methods used for detecting faecal proteolytic activity including our variant of RED have certain advantages - they are cheap, easy and quick to perform and can describe the situation in the bowel with regard to the status of pancreatic proteases and their lytic activity. However, all of them also produce the same kind of errors. The cause of falsely positive results can be binding of hydrolases of pancreatic origin on the intestinal surface glycocalyx (Sandholm and Scott 1979; Williams and B att 1988). This can be excluded by dietary supplementation with soybean test meal. Soybean contain plant lectins, which can effectively release pancreatic proteases from the glycocalyx so that they are subsequently flushed into the intestinal content (Sandholm and Scott 1979). The lectins can protect pancreatic hydrolases from proteolytic damage in the bowel as well (Westermarck and Sandholm 1980). Unfortunately, it was not possible to use this soybean stimulation in all dubious cases in our study, because of poor owner compliance. To avoid discrepancy among the results of RED in our study, values obtained after the soybean stimulation were finally excluded.

Other possible reasons for falsely positive results of RED are low neurohumoral stimulation of the pancreas (due to anorexia), lack of disposable proteins used for synthesis of pancreatic enzymes, low concentration of enzymes in the lumen of the bowel due to dilution (diarrhoea), prolonged persistence of the intestinal content in the bowel and subsequent destruction of the enzymes, presence of small intestinal bacterial overgrowth or intestinal parasites etc. (Williams and Batt 1988; Spillmann 1996).

There is also a possibility of falsely negative results of RED; in theory some species of enteric bacteria (e.g. Clostridium spp.) may produce substantial quantities of peptidase with a chymotrypsin-like substrate specificity (Williams and Batt 1988). Another cause can 
be oral enzyme substitution (Fischer and Müller 1994; Spillmann 1996), which should be interrupted at least 3 days before taking samples. The risk of falsely negative results is neglected after interruption of enzyme replacement therapy.

Even though the results of TLI have always been described as very reliable, we could discuss some exceptional situations with a high probability of falsely negative results. These may include the obstruction of the pancreatic duct (Williams and Batt 1988; Spillmann 1996), inherited deficiency of intestinal enteropeptidase or pancreatic enzymes excluding trypsinogen (but these situations have never been described in the dog so far) (Williams and B att 1988; S pillmann 1996). The same applies to EPI caused by chronic recurrent pancreatitis (Williams and B att 1988) or acute pancreatitis with high serum TLI and presenting as EPI (Keller 1990), EPI with concurrent renal insufficiency without azotemia (Spillmann 1996), in cases of extreme malnutrition (Hall and Hagemoser 1990) or feeding the dog shortly before taking the serum sample (Williams and Batt 1988; Fischer and Müller 1994). Changes in dietary protein content also have significant effect on serum TLI concentration, where higher content of protein in the diet caused an elevation of TLI levels (Williams and B att 1988; Carro and Williams 1989). Increased levels of serum TLI in dogs were found after dexamethasone administration (Lucena et al. 1999). Methods assessing the faecal proteolytic activity or bentiromide PABA test would be probably more valuable in these rare situations.

Our modification of RED thus represents a quick, cheap and easy method that can exclude the cases where the cause of chronic diarrhoea is not EPI. However, as some of these cases can result as RED positive, it is necessary to confirm the positive RED results by means of serum TLI determination.

\section{Diagnostika exokrinní pankreatické insuficience u psa metodou radiální enzymodifuze}

Exokrinní pankreatická insuficience (EPI) je závažnou přǐčinou chronického průjmu u psů, kterou je nutno spolehlivě vyloučit ještě před prováděním endoskopického vyšetření střeva. Cílem práce bylo ověřit diagnostickou využitelnost radiální enzymodifuze (RED) jako jedné z metod založených na stanovení proteolytické aktivity féces u psů. V práci je popsána modifikace RED, kde byl jako substrát pro pankreatické proteázy použit namísto Ca-parakaseinátu vodný roztok sušeného mléka. Jako referenční metoda bylo použito stanovení imunoreaktivity trypsinu a trypsinogenu (TLI) s uváděnou $100 \%$ specifitou i citlivostí. Metoda byla ověrena u 24 psủ převážně s chronickým průjmem, a to u různých plemen s prevahou německých ovčákủ. Jako kontrola sloužilo 10 klinicky zdravých psů. U každého psa byly vyšetřeny 3 vzorky trusu. Současně bylo u všech psů vyšetřeno krevní sérum pomocí TLI. Byla vypočtena 100\% citlivost a 75\% specifita RED. Jsou diskutovány možné příčiny falešně pozitivních a falešně negativních výsledků RED a TLI. Radiální enzymodifuze se osvědčila jako rychlá, levná a snadno proveditelná metoda vhodná ke spolehlivému vyloučení těch př́ípadů chronického průjmu, kde př́činou není EPI. $\mathrm{S}$ ohledem na nižší specifitu je však nutno pozitivní výsledky RED potvrdit pomocí TLI.

\section{Acknowledgements}

This work was supported by the grant of the Ministry of Education, Youth and Sports of the Czech Republic No. 161700 002. The authors are grateful to late Prof. M. Sandholm for providing the procedure and Prof. MVDr. J. Smola, CSc. for his valuable advice and approach to laboratory facilities.

\section{References}

BOARI, A, WILLIAMS, DA, FAMIGLI BERGAMINI, P 1994: Observations on exocrine pancreatic insufficiency in a family of English Setter dogs. J Small Anim Pract 35: 247-250

CARRO, T, WILLIAMS, DA 1989: Relationship between dietary protein concentration and serum trypsin-like immunoreactivity in dogs. Am J Vet Res 50: 2105-2107 
FISCHER, S, MÜLLER, E 1994: Exokrine Pankreasinsuffizienz beim Hund. Der Praktische Tierarzt 75: 116-117 FREUDIGER, U 1991: Physiologie, Pathologie, Labor und Therapie der exokrinen Erkrankungen der Bauchspeicheldrüsse beim Hund. Kleintierpraxis 36: 5-16

HALL, EJ, BOND, PM, McLEAN, C, BATT, RM, MCLEAN, L 1991: A survey of the diagnosis and treatment of canine exocrine pancreatic insufficiency. J Small Anim Pract 32: 613-619

HALL, DJ, HAGEMOSER, WA 1990: The use of serum trypsin-like immunoreactivity for the diagnosis of canine exocrine pancreatic insufficiency. Iowa State Univ Vet 52: 8-10

KELLER, ET 1990: High serum trypsin-like immunoreactivity secondary to pancreatitis in a dog with exocrine pancreatic insufficiency. J Am Vet Med Assoc 196: 623-621

LUCENA, R, GINEL, PJ, NOVALES, M, MOLLEDA, JM 1999: Effects of dexamethasone administration on serum trypsin-like immunoreactivity in healthy dogs. Am J Vet Res 60: 1357-1359

RÄIHÄ, M, WESTERMARCK, E 1989: The signs of pancreatic degenerative atrophy in dogs and the role of external factors in the ethiology of the disease. Acta Vet Scand 30: 447-452

RALLIS,T, ADAMAMA-MORAITOU, KK, SOUBASIS, N 1999: Canine exocrine pancreatic insufficiency: clinical and laboratory findings in 15 spontaneous cases. Canine Practice 24:12-15

SANDHOLM, M, SCOTT, ML 1979: Binding of lipase, amylase and protease to intestinal epithelium as affected by carbohydrates and lectins in vitro. Acta Vet Scand 20: 329-342

SIMPSON, KW, SIMPSON, JW, LAKE, S, MORTON, DB, BATT, RM 1991: Effect of pancreatectomy on plasma activities of amylase, isoamylase, lipase and trypsin-like immunoreactivity in dogs. Res Vet Sci 51: 78-82

SPILLMANN, T 1996: Zur Diagnostik der exokrinen Pankreasinsuffizienz beim Hund - Möglichkeiten und Grenzen der Labordiagnostik chronischer Pankreatopathien. Kleintierpraxis 41: 653-668

SPILLMANN, T, EIGENBRODT, E, SZIEGOLEIT, A 1998: Die Bestimmung und klinische Relevanz der fäkalen pankreatischen Elastase beim Hund. Tierärztl Prax 26: 364-368

WIBERG, ME, SAARI, SAM, WESTERMARCK, E 1999: Exocrine pancreatic atrophy in German shepherd dogs and rough-coated collies: An end result of lymphocytic pancreatitis. Vet Pathol 36: 530-541

WESTERMARCK, E, BATT, RM, VAILLANT, C, WIBERG, M 1993: Sequential study of pancreatic structure and function during development of pancreatic acinar atrophy in a German Shepherd dog. Am J Vet Res 54: 1088-1094

WESTERMARCK, E, SANDHOLM, M 1980: Faecal hydrolase activity as determined by radial enzyme diffusion: a new method for detecting pancreatic dysfunction in the dog. Res Vet Sci 28: 341-346

WILLIAMS, DA, BATT, RM 1988: Sensitivity and specificity of radioimmunoassay of serum trypsin-like immunoreactivity for the diagnosis of canine exocrine pancreatic insufficiency. J Am Vet Med Assoc 192: 195201 